\title{
Managing conflicting water resources requirements in coastal wetlands: case study Pevensey Levels, UK
}

\author{
S. B. Mitchell \& D. Diston \\ School of the Environment, University of Brighton, Lewes Road, \\ Brighton, UK
}

\begin{abstract}
The Pevensey Levels is an area of reclaimed coastal wetlands located in East Sussex, UK. Agricultural and land-drainage activities dominate land use and have impacts on water quality within the Levels. The dense arterial ditch network which drains the levels suffers from nutrient enrichment, in particular orthophosphate $\mathrm{PO}_{3}{ }^{4-}$ and inorganic nitrogen compounds $\left(\mathrm{NH}_{4}{ }^{+}, \mathrm{NO}_{2}{ }^{-}\right.$and $\left.\mathrm{NO}_{3}{ }^{-}\right)$. The primary drivers behind the increase in nutrient concentrations are agricultural intensification, conversion to arable farming and point source pollution (particularly from two nearby Sewage Treatment Works). This study describes water quality data from January 1994 to July 2005 in order to discern temporal and spatial nutrient trends. It is evident that water quality within the Pevensey Levels is degraded. Concentrations of $\mathrm{NH}_{4}^{+}, \mathrm{NO}_{2}{ }^{-}$and $\mathrm{PO}_{3}{ }^{4}$ throughout both major catchments are elevated, whilst concentrations of $\mathrm{NO}_{3}{ }^{-}$ are lower than expected, indicating that many sites may also experience problems with low levels of dissolved oxygen. The Pevensey/Hurst Haven catchment was found to have significantly higher concentrations of all determinands, primarily as a result of effluent discharge from the Hailsham STWs. The Wallers Haven catchment was also found to experience water quality problems, but to a lesser extent. Over the period of observation, chemical $\mathrm{P}$ stripping was introduced at the Hailsham STWs, resulting in a significant decrease in recorded $\mathrm{PO}_{3}{ }^{4-}$ concentrations. However, although external nutrient loading has decreased, water quality recovery limited. Suggestions are made for further research into the reasons for this lack of improvement.
\end{abstract}

Keywords: coastal wetlands, eutrophication, nitrate, phosphate, sewage treatment, ditch water level management. 


\section{Introduction}

Amongst all of the ecosystems in the world, those of the wetland environment are among the most ecologically diverse, biologically valuable, and most at risk of degradation or loss. Wetland disappearance continues to occur at an alarming rate and it is estimated that more than $90 \%$ of Europe's wetlands have been lost [1]. In conjunction with providing unique habitats for varied flora and fauna, wetland systems have the ability to purify influents, effectively acting a buffer zone between terrestrial and aquatic ecosystems, consequently discharging water of a higher standard than originally received. Of the many drivers behind wetland loss and degradation, agricultural intensification and poor land use management are the most common. Nutrient enrichment, and subsequent eutrophication, from both point and diffuse sources, have the potential to severely disrupt wetland species composition, often replacing valuable/rare species with less desirable ones. As the problems associated with wetland loss are becoming widely acknowledged, conservation and remediation schemes have an increased status within the environmental agenda. The current study forms part of a larger, EU-wide Lakepromo project [2] that seeks to address some of the issues related to environmental improvement of lakes and wetlands within the constraints of national and European legislation and development goals.

\section{Study site description}

The Pevensey Levels $\left(0^{\circ} 20^{\prime} \mathrm{E}, 50^{\circ} 50^{\prime} \mathrm{N}\right)$ are an area of reclaimed wet coastal grassland, covering approximately 3500ha (See Figure 1). Since 1977, the majority of the Pevensey Levels have been designated as a Site of Special Scientific Interest (SSSI), mainly due to the considerable number of rare plants and invertebrates present. The Levels are also a candidate RAMSAR site of International Wetland Importance and, until recently, were a Special Protection Area under the European Union Directive on the Conservation of Wild Birds (79/409/EEC). The Levels host two National Nature Reserves which are of specific avian importance for both over-wintering and breeding bird populations. The SSSI was re-notified in 1990, resulting in the total area decreasing from 4,112 ha to 3,501 ha. Loss of biological interest was the primary driver behind re-notification. The Hurst Haven and the Horse Eye Sewer are designated as Sensitive Areas (Eutrophic) under the EU Urban Waste Water Treatment Directive (91/271/EEC).

Before 1959 the Levels were almost entirely comprised of permanent grassland utilised for grazing during summer and subject to periodic winter flooding. Pumped drainage systems facilitated the extent of arable farming and the extension of the grazing; estimations put the total area under arable cultivation as of 1990 being approximately 20\% [3]. Much of the land in the central gravity drained Manxey Level is now being used for organic sheep farming, arable cultivation is now limited to a small section in the south west of the Levels. 


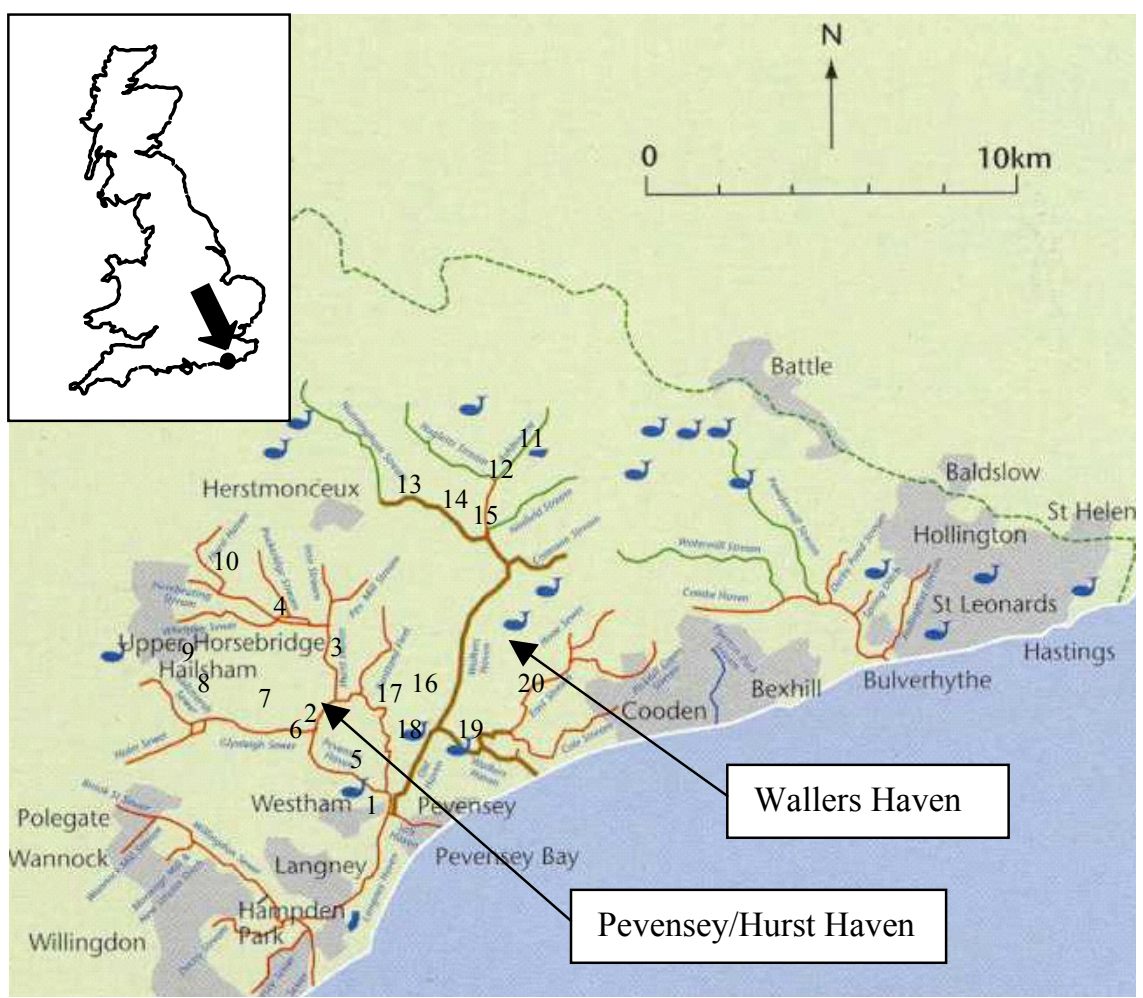

Figure 1: The Pevensey Levels. Figures refer to monitoring points (see text for further details).

Whilst the main management concern for the western side of the Levels is the control of discharges (in particular nutrient enrichment from the Hailsham STWs), the management concerns for the eastern side of the Levels are twofold:

- Wallers Haven water abstraction;

- Agricultural diffuse pollution.

As the features of ecological interest are primarily found in the smaller field ditches and drains, it is of paramount importance that diffuse pollution from the surrounding agricultural land is kept to a minimum in order to reduce nutrient transport. To ensure this a number of environmentally aware management schemes are currently in operation within the Levels.

As of 1997, approximately $60 \%$ of the Pevensey Levels Ramsar/SSSI area is subject to some manner of environmental management agreement [2]. A new nationwide agri-environmental scheme, the Environmental Stewardship scheme [4] seeks to build upon existing agreements, whilst encouraging new participants. It has been shown that these environmental agreements, which cover most of the SSSI, have significantly reduced nutrient inputs from agriculture [5]. 
The sustainable management of water abstraction for human use is pivotal to the 'health' of the Levels, in particular the Wallers Haven, and the surrounding ditches which it feeds. Poor abstraction management may lead to insufficient volumes of water available for nutrient dilution, therefore compounding water quality issues and increasing nutrient concentrations within the system. In conjunction with increased nutrient concentrations and subsequent eutrophication, reductions in flow may lead to a change in species composition and cause an increase in the presence of scrub (Phragmites australis).

The Levels have an extremely complex hydrological regime due to the nature of progressive land reclamation and the subsequent drainage improvements. The arterial drainage network that is evident today (which is built upon historic drainage channels) has a total length of $715 \mathrm{~km}$ and is controlled by 18 pumps and numerous structures. There are 2 major catchments in the Levels, the Pevensey Haven (7,315 ha) and Waller's Haven/East Stream (10,378 ha). Sluices on the Wallers Haven and Pevensey Haven prevent any saltwater intrusion, allowing the drainage networks to act as a reservoir during the summer months (storing water for drain feeding in order to provide wet fences), and as a more typical river system during winter. Surface inflows and outflows are minimal; therefore the hydrological of the Levels is dependent on the balance between precipitation and evaporation. The surface inputs that are of importance are the Hailsham sewage treatment works which discharge effluent into the northwestern area of the Levels; in particularly dry summers these can account for $20 \%$ of hydrological input. The effluent released form the Hailsham STWs is originally sourced from the River Cuckmere therefore representing an intercatchment transfer into the hydrological system. Estimates of mean annual rainfall are around $777-800 \mathrm{~mm}$.

The Pevensey levels exhibit a hydroseral sequence which cannot be equalled in the UK. The network of ditches, which are kept in different stages of hydroseral succession, allow the creation of viable habitats for a wide range of rare flora and fauna and in comparison to the fields and the main channels are more important for biodiversity. Ditches are managed on a 7-10 year sequence, at the end of which they are dredged to prevent further succession, thereby returning them to an earlier stage of development. Out of the 160 plants classified as aquatic in the British Isles, 110 have been recorded on the Pevensey Levels, of which 37 are designated either rare or local.

In addition to a wide range of aquatic flora and fauna, the Pevensey Levels host one of only two UK populations of the Fen Raft Spider (Dolomides plantarius) and are one of the most important sites in the UK for freshwater Molluscs. The Pevensey Levels also provide vital habitats for both breeding and over-wintering bird populations, including lapwing, common snipe and species of warbler. Over-wintering bird populations can be extremely sensitive to human disturbance and it is therefore of paramount importance that access to recreation should be carefully controlled and planned in order to minimise stress. Further details on these and related environmental issues may be found in Diston [6]. 


\section{Discussion}

In considering the water quality characteristics of the ditches in the Pevensey Levels it is most instructive to focus on the prevalence of N and P, as these have the greatest control on eutrophication. Monthly monitoring is carried out by the Environment Agency for England and Wales at sites indicated as numbers on Figure 1. There are significant spatial variations of all forms of $\mathrm{N}$ and $\mathrm{P}$ within the Pevensey Levels, as illustrated in figures 2 and 3. Concentrations of $\mathrm{NH}_{4}{ }^{+}$ and $\mathrm{NO}_{2}{ }^{-}$and $\mathrm{PO}_{3}{ }^{4-}$ are significantly elevated at the majority of sites, whilst many sites experience lower than anticipated levels of $\mathrm{NO}_{3}^{-}$, possibly indicating low levels of dissolved oxygen.

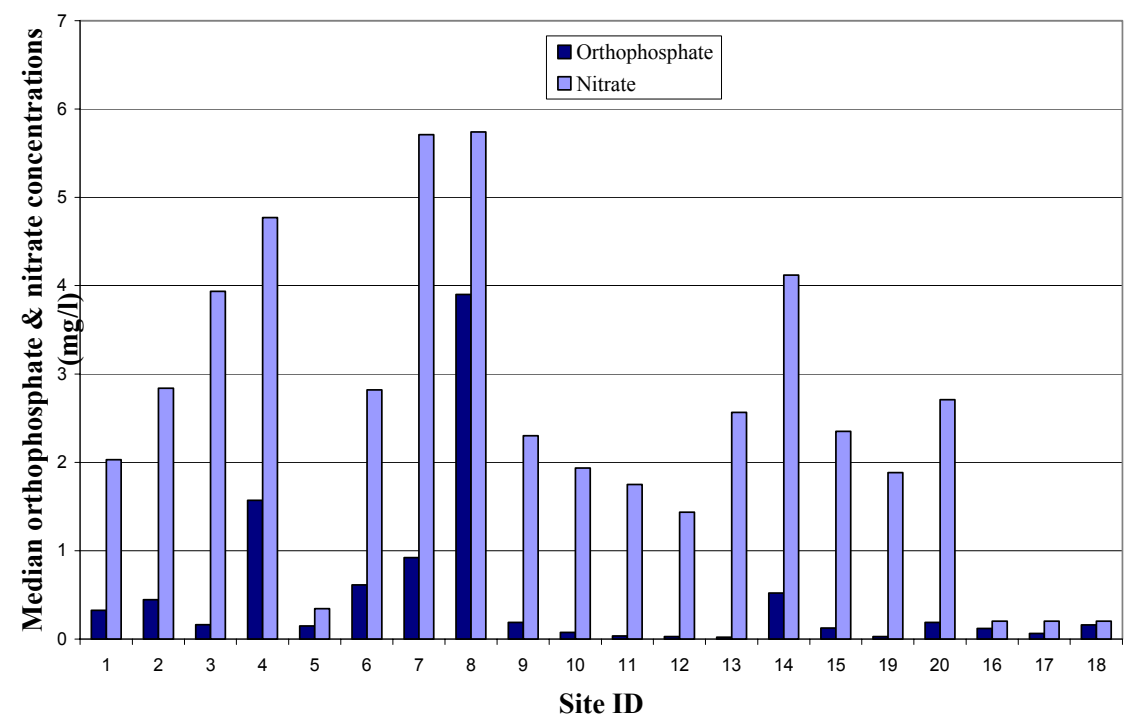

Figure 2: Median $\mathrm{PO}_{3}{ }^{4-}$ and $\mathrm{NO}_{3}{ }^{-}$Concentrations across all Pevensey Levels sites.

Phosphorus concentrations in natural UK surface waters are usually around $0.005-0.002 \mathrm{mg} / \mathrm{l}$, with distinct seasonal variations relating to vegetation uptake (high during summer) and vegetation decay (high during winter). Phosphorus loss from agricultural land occurs mainly via overland flow and via drainflow and is predominantly lost in particulate form during rainfall events, which is the primary mechanism for $\mathrm{P}$ transportation within agricultural systems. To a lesser extent, P may also be transported in solution. Where soil concentrations of $\mathrm{P}$ are elevated above background concentrations, losses to watercourses will be greater [7]. Elevated levels could be due to fertiliser run-off, effluent from STW (domestic wastewater phosphorus sources are dominated by synthetic detergents and human excreta). It is evident from recent water quality data that levels of 
orthophosphate are elevated; the median concentration of $\mathrm{P}$ (as orthophosphate) across the 10 Pevensey/Hurst Haven monitoring sites is $0.37 \mathrm{mg} / \mathrm{l}$; the median concentration of $\mathrm{P}$ across all 20 monitoring sites is $0.154 \mathrm{mg} / \mathrm{l}$. As concentrations are greater than the $0.1 \mathrm{mg} / 1$ limit usually applied in the English Nature condition assessment, this would suggest that many more compartments would be classified as being in unfavourable condition.

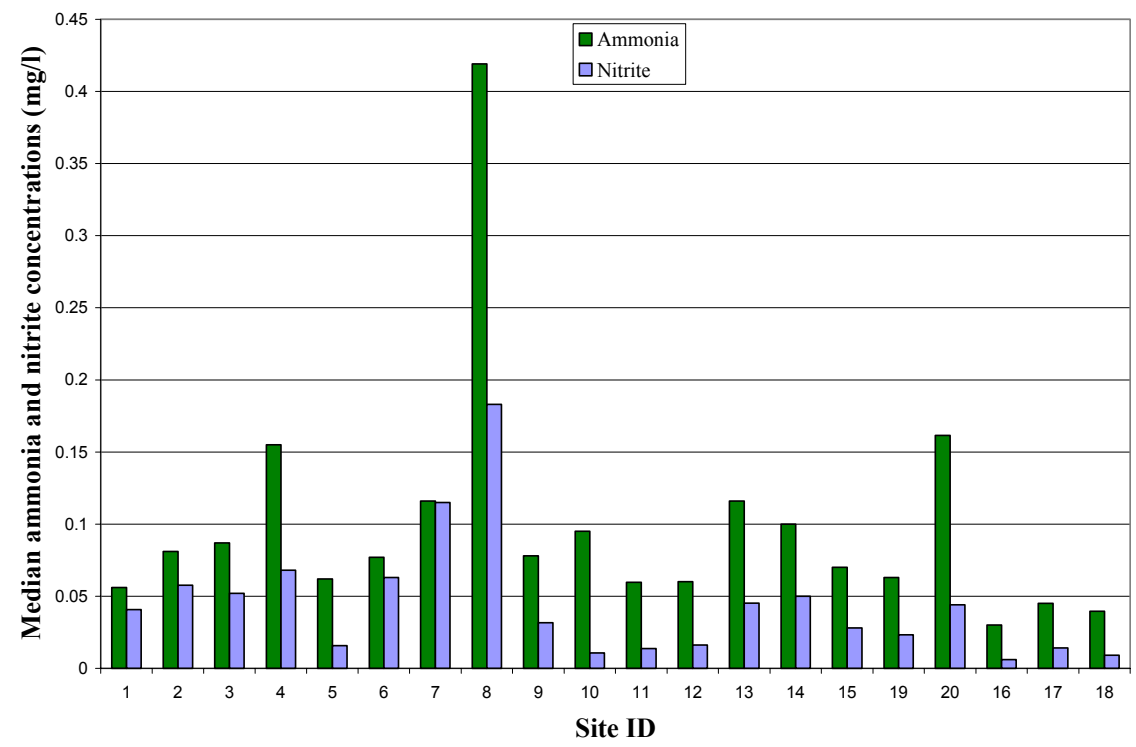

Figure 3: Median $\mathrm{NH}_{4}{ }^{+}$and $\mathrm{NO}_{2}^{-}$Concentrations across all Pevensey Levels sites.

Phosphorus stripping by chemical precipitation was introduced at both Hailsham STWs in April 2003, and it is evident from data that there is a distinct difference in the levels of $\mathrm{P}$ (as orthophosphate) before and after P stripping was introduced. The pre-stripping median across all 10 Pevensey/Hurst Haven sites was $0.78 \mathrm{mg} / \mathrm{l}$, whereas the post-stripping median is $0.22 \mathrm{mg} / \mathrm{l}$. Although poststripping levels of $\mathrm{P}$ are still elevated, it is evident that concentrations have been decreasing in recent years. 8 out of the 10 sites assessed showed an overall decrease in median $\mathrm{P}$ concentrations after the introduction of $\mathrm{P}$ stripping, see figure 4 .

The site that exhibited the largest difference between pre and post-stripping $\mathrm{P}$ concentrations was site 8, directly downstream of Hailsham South STW and therefore the site most likely to give an indication of whether the phosphorus stripping at the STW has been effective. Site 8 had the highest pre-stripping median concentrations of $\mathrm{P}, 5.38 \mathrm{mg} / \mathrm{l}$, possibly as a result of high concentrations in STW effluent. Upon introduction of $\mathrm{P}$ stripping, concentrations at site 8 dropped significantly; the site has a post stripping value of $0.685 \mathrm{mg} / \mathrm{L}$. Although this site has experienced the greatest decrease in concentrations, 
concentrations are still the highest of the 10 Pevensey/Hurst Haven monitoring sites, indeed the highest median concentration across all 20 Pevensey Levels monitoring sites. Besides point source pollution, diffuse pollution may exert considerable influence upon the nutrient budget. The proximity of a number of farms, the nearest being Slyes Farm $(0.5 \mathrm{~km}$ upstream), may be significant, although at this stage it is not possible to ascertain what percentage of the nutrient budget comes from agricultural activities.

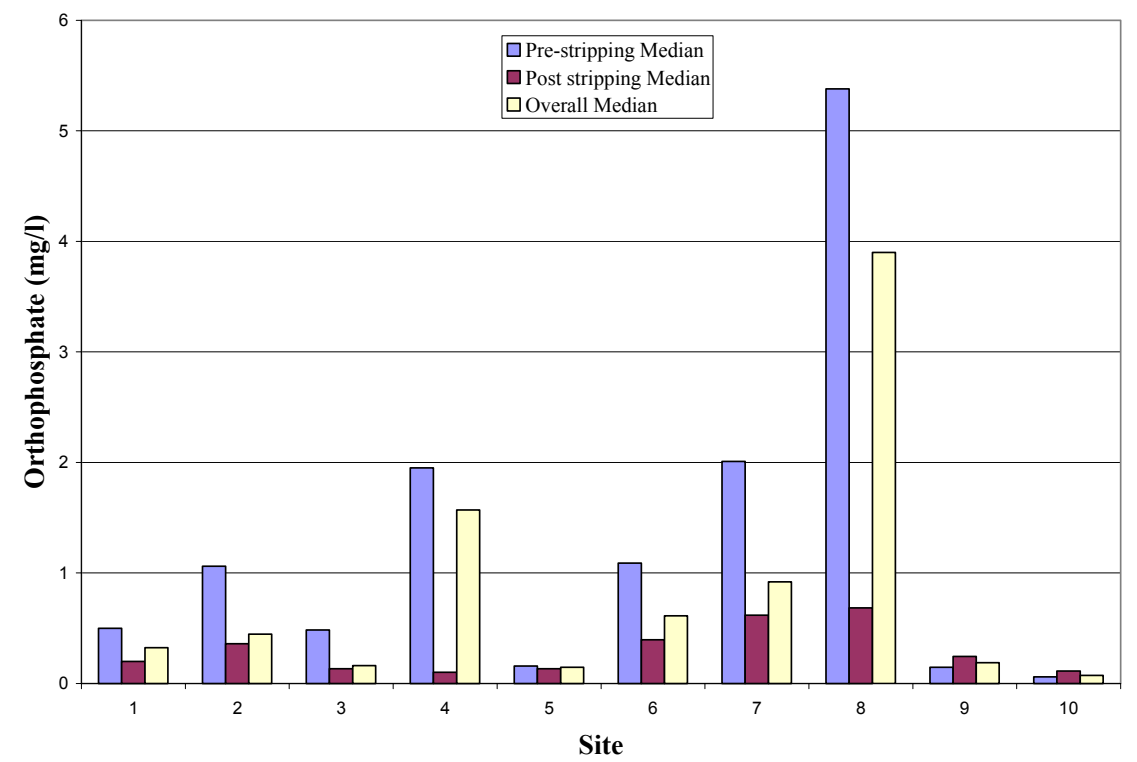

Figure 4: Pre, post-stripping and overall levels of orthophosphate across all Pevensey/Hurst Haven sites.

In contrast to the Pevensey/Hurst Haven drainage basin, the primary risk to the water quality of the Wallers Haven drainage basin is diffuse pollution. There are point source discharges, notably the Windmill Hill STW, but are minimal in terms of potential impact compared to point sources within the Pevensey/Hurst Haven catchment. Generally, the quality of the water found in the Wallers Haven catchment is better than that of the Pevensey/Hurst Haven.

Table 1: Median (mg/l) values of ammonia, nitrate, nitrite and orthophosphate.

\begin{tabular}{lllll} 
Site & $\mathbf{N H}_{\mathbf{4}}{ }^{+}$ & $\mathbf{N O}_{\mathbf{3}}{ }^{-}$ & $\mathbf{N O}_{2}{ }^{-}$ & $\mathbf{P O}^{\mathbf{3}}{ }^{-}$ \\
\hline Pevensey Haven & 0.084 & 2.83 & 0.0548 & 0.3845 \\
Wallers Haven & 0.0665 & 2.1175 & 0.0256 & 0.0315 \\
Entire Levels area & 0.0775 & 2.325 & 0.03615 & 0.161
\end{tabular}


As illustrated in Table 1, the water quality in the Wallers Haven is of superior quality to that of the Pevensey/Hurst Haven. It has lower median values of all the studied determinands, with a particular difference being noted in orthophosphate concentrations.

There are numerous classification systems used to determine the trophic status of bodies of water, for example Chapman [8]. As the water quality data show, $70 \%$ of the sites have concentrations of $\mathrm{P}>0.1 \mathrm{mg} / \mathrm{l}$, therefore suggesting they are, or are at risk of being, in a eutrophic state.

The western half of the Levels, the Pevensey/Hurst Haven drainage system, experiences significantly higher nutrient concentrations than the eastern half, the Wallers Haven drainage system. Data sets indicate that all sites, with the exception of site 10, within the Pevensey/Hurst Haven system may be eutrophic to hypertrophic; whereas within the Wallers Haven system, only site 15 would be classified as being eutrophic-hypertrophic. Previous studies have indicated that the Pevensey Levels are naturally mesotrophic [3].

It is thought that the eutrophication of the Pevensey/Hurst Haven has led to the increased incidence of floating pennywort (Hydrocotyle ranunculoides). Native to North America, floating pennywort was introduced to the UK via the aquatic nursery trade, for use in ponds and tropical aquaria. It is thought to have entered the Levels via one of the Hailsham STWs. Under the correct conditions, floating pennywort can double its biomass in 3 days, and has the potential to completely choke ditches. Pennywort favours slow moving shallow waterbodies and can be particularly prevalent in the ditch system.

Pennywort is a problem for two main reasons:

- Ditches/waterbodies may become totally covered with a dense mat, therefore significantly reducing amount of light able to penetrate, thereby reducing plant/animal activity and severely disrupting the ecological balance;

- Dense mats of floating pennywort may appear to be solid ground, resulting in the drowning of livestock.

Floating pennywort is thought to be limited by nitrate, with leaf size being proportional to concentrations. However, limitation by phosphorus will occur below $15 \mu \mathrm{g} / \mathrm{l}$. Due to the elevated levels of $\mathrm{P}$ within the levels, it is unlikely that $\mathrm{P}$ limitation will occur. The level at which nitrate limitation will occur is unknown at present.

To date, floating pennywort appears to mainly inhabit ditches on the western side of the Levels. Current distribution may have more relationship to the location of its original introduction than water quality, as distribution seems to be more strongly correlated with water drainage patterns than nutrient concentration patterns. The current management of pennywort relies on manual cutting and removal.

\section{Conclusions and recommendations}

Water quality within the Pevensey Levels is degraded and the majority of sites exhibit high concentrations of $\mathrm{PO}_{3}{ }^{4-},>0.1 \mathrm{mg} / \mathrm{l}$. Concentrations of both $\mathrm{NH}_{4}{ }^{+}$and 
$\mathrm{NO}_{2}{ }^{-}$are significantly elevated throughout the Levels area, whilst levels of $\mathrm{NO}_{3}{ }^{-}$ appear to be very low at many sites, $<5 \mathrm{mg} / \mathrm{l}$. The Wallers Haven tends to have water quality of a higher standard than the Pevensey/Hurst Haven, and this could be influenced by a number of factors. The primary driver behind nutrient enrichment within the Pevensey/Hurst Haven drainage system is effluent discharge from the Hailsham STWs, located in the north-west of the catchment. Is has been shown from downstream nutrient profiles that elevations in all determinands increase immediately downstream of effluent discharge points. However it is obvious from elevated nutrient concentrations upstream that agricultural land use may also be contributing to the problem. Since chemical $\mathrm{P}$ stripping has been introduced at both STWs, concentrations recorded within the Pevensey/Hurst Haven drainage system have decreased, but this may be retarded by $\mathrm{P}$ release by channel sediments. The likely response of ecological features to reduction of point source phosphorus is currently not known.

Orthophosphate data suggest that many areas of the levels are, or are at risk of becoming eutrophic. There is an apparent connection between nutrient enrichment and the growth of Hydrocotyle ranunculoides (floating pennywort) which is known to be related to concentrations of nitrate and phosphate. Current strategies to limit the concentration of dissolved phosphate by $\mathrm{P}$ stripping at Hailsham STWs appear at present to be having little effect on these invasive macrophytes.

The following recommendations are made for the continuation of this study:

1. Continued monitoring of concentrations of $\mathrm{N}$ and $\mathrm{P}$ at four key sites by hand-held Hach devices as well as more robust laboratory measurements in order to try to identify seasonal variations in nutrient distribution post P-stripping at the Hailsham STWs.

2. Research into the impact of floating pennywort upon species of ecological interest.

3. Research into floating pennywort movement/distribution and relationship with water quality.

4. Investigation of the possibility of using borate and faecal tracking methods as tracers in order to apportion sources of nutrient enrichment.

5. Identification of more hydrogeomorphically similar wetlands in order to discern possible redemptive strategies.

\section{Acknowledgements}

This work is funded under the EU-Interreg IIIC programmes 'Lakepromo Tools for Lake and Wetland Restoration Processes'. The authors would like to thank staff at the Environment Agency, South East Water and Southern Water for supplying water quality data and various reports relating to the Pevensey Levels. Thanks must also be given to Dr Dave Gasca Tucker, Dr Hadrian Cook and Richard Reeves for hosting site visits and providing useful data. 


\section{References}

[1] Mitsch, W. J., \& Gosselink, J. G. Wetlands. $3^{\text {rd }}$ ed. John Wiley \& Sons Chichester, 2000.

[2] EU-Interreg IIIc 'Lakepromo: Tools for Lake and Wetland Restoration Processes'

http://webd.savonia-amk.fi/projektit/markkinointi/lakepromo/default.aspx

[3] Atkins Study to inform the appropriate assessment of the Pevensey Levels Ramsar. Report prepared for The Environment Agency. March 2004.

[4] Department of Environment, Food and Rural Affairs (Defra) http://www.defra.gov.uk/erdp/schemes/es/default.htm

[5] Atkins. Pevensey Levels Water Balance, AMP 3 Phase 2 Study of Wallers Haven. Report prepared for South East Water. May 2002.

[6] Diston, D. The Pevensey Levels Review of current knowledge and preliminary findings from the EU Lakepromo research project, University of Brighton report for EU-Interreg IIIc, 2005.

[7] Withers, P.J.A. \& Lord, I.L. Agricultural nutrient inputs to rivers and groundwaters in the UK: policy, environmental management and research needs. The science of the Total Environment, 282-283, pp 9-24, 2002

[8] Chapman (Ed) Water Quality Assessments, $2^{\text {nd }}$ Ed. Spon publ. London, 1996. 